ACTA UNIVERSITATIS LODZIENSIS

FOLIA LITTERARIA POLONICA 6(36) 2016

http://dx.doi.org/10.18778/1505-9057.36.11

Teresa Dalecka*

\title{
The (Non)Presence of Julian Tuwim in Lithuania
}

The relatively poor reception of Julian Tuwim's works in Lithuania stems from the 1960s. In that period, unofficial literature circulated the country, influencing society as a form of cultural resistance, sole means to preserve national identity. Literary works became synonymous with defending culture and society. One of the dominating directions of the development of Lithuanian literature was reconstructing bonds with the pre-war national-agricultural vision of the world and historical memory. The second direction was, often through translations, reconstructing Western modernistic trends ${ }^{1}$. Lithuanian writers were searching for various forms of modified avant-garde trends in Western poets, Julian Tuwim among them.

Having reclaimed independence in 1991, Lithuanian literature became similar to Western literature. A lot of new opportunities opened up. Among the most interesting ones, there were phenomena like: unstable identity of the subject, popularity of grotesque, disappearance of lyricism in poetry, intertextuality, dominance of essay in prose, and stylistic experiments including merging highbrow and mass literature ${ }^{2}$. Contemporary Lithuanian writers reflect various outlooks and philosophies in their works. Young authors feel less overwhelmed by tradition than their predecessors. At the same time, the reasons to rebel against literary canons are diminishing:

Currently, the most important issue is the audience of literature and the question of the place for subjective works in a chaotic world of commercialised society, ruled by market competitiveness, along with modernised communication ${ }^{3}$.

However, Lithuanian prose writers such as Riardas Gavelis, Sigitas Parulskis, Marius Ivaškeviius, don't want to borrow Western models and also often

* Dr, e-mail: teresa.dalecka@flf.vu.lt, Centre of Polish Studies at Vilnius University, Vilnius, Lithuania [Filologijos fakultetas, Polonistikos centras, Vilniaus Universitetas, Universiteto gatvè 5, Vilnius, LT-01513, Lietuva].

${ }^{1}$ See M. Kvietkauskas, Pędzac przez tunel czasu. Nowe kierunki w literaturze litewskiej, trans. Z. Mrozikowa, "Literatura na Świecie" 2005, no. 1-2, pp. 324-325.

${ }^{2}$ Ibidem, pp. 323-337.

${ }^{3}$ Ibid, p. 337. 
fossilised or imposed versions of their culture and history. They draw from folk tales, local legends, the communistic past, their own biographies, and their own immediate surroundings. All of them are connected by one fundamental gesture: they are lifting the curse from the world of post-Soviet bloc countries; they dare to consciously inhabit the land ravaged by twenty years of history and to restore its lost values ${ }^{4}$.

As for Lithuanian poetry, old religion and religious mentality constitute a still significant part. Researchers say that the focus on the East, the Oriental philosophy in contemporary Lithuanian poetry (among others) exceeds the limits of any trend or popularity. If the interest in the East in early $20^{\text {th }}$ century literature was a reflection of tendencies observed in European literature, then, starting from the Soviet period, the phenomenon took on unique proportions ${ }^{5}$.

That is why Polish literature and literary studies are a big challenge for specialists in Lithuanian studies. According to the researcher Audinga PeluritytèTikuišiene, despite many shared historical moments, an inherited sense of solidarity, the two nations have fundamentally different languages. If we agree that every language is a different approach to the world, Polish and Lithuanian are two separate worlds: on the one hand we have Poles who are arguably the most zealous Catholics in Europe, on the other, the pagan Lithuanians whose Christian awareness is problematic even to themselves ${ }^{6}$.

The East provides Lithuanian writers with answers to questions which are valid also in Christian thought: community and the individual, freedom and responsibility, faith and reason. These are the differences between the Polish and the Lithuanian literary mentality. Poles are reflecting on the Christian advent of their culture. It is this awareness of the Europeanism of culture that is one of the most interesting issues for Lithuanian writers and literary specialists?

From what has been said so far, it's clear that the reception of Polish literature in Lithuania is a complex issue. There was a long-lasting tendency to broaden the area of Lithuanian literature by making it incorporate Polish-language authors related with Lithuania. That's how national literature broadened its horizons ${ }^{8}$. According to Algis Kaleda, in the past, works by Polish authors were treated selectively, mostly with consideration of the pragmatic aspect ${ }^{9}$. In Polish literature, researchers sought points of contact with their own problems. As in other litera-

\footnotetext{
${ }^{4}$ See: I. Kędzierski, Rybatci znad Niewiaży, http://witryna.czasopism.pl/pl/gazeta/1037/1127/ 1166/ [accessed: 15.10.2013].

${ }^{5}$ A. Peluritytė-Tikuišienè, [answers to the questionnaire: How they read us abroad], "Czytanie Literatury" 2012, no. 1, p. 345.

${ }^{6}$ Ibidem

${ }^{7}$ Ibidem, p. 347.

${ }^{8}$ A. Kalèda, Kaimynų literatūra - kaip sava ir kaip pažistama?, "Krantai” 2013, no. 148, p. 27.

${ }^{9}$ Ibidem
} 
tures, they sought the links missing in their own culture. A translated text stopped representing its own culture and entered into a dialogue with the target literature, proposing new models, languages and criteria.

Currently in Lithuania, there are attempts to adapt texts written in the Grand Duchy of Lithuania, and in Lithuania in other languages than Lithuanian, i.e. in Polish. These Polish texts are considered as elements of a broadly understood Lithuanian cultural heritage. Their "assimilation" and introduction into Lithuanian society appears to be a fundamental task of a few specialists in Lithuanian studies.

The translations of works of Polish authors of Lithuanian descent were supposed to, and still primarily have to, fulfil the national-patriotic aspirations of Lithuanians, showcase the country's famous past, the deeds of its leaders, the unique national identity, the beauty of nature and other quasi-mythical ornaments $^{10}$. That is why there are translations of mostly those authors whose works dealt with the problematic past of the Grand Duchy of Lithuania and the creation of Lithuania's artistic landscape. Similar tendencies are characteristic of every age, but now they manifest themselves mainly through reissues of Czesław Miłosz's works (or maybe only attempts to assimilate them), as well as translating into Lithuanian and publishing novels such as Józef Mackiewicz's Road to Nowhere. That is the reflection of one of the aspects of the reception of Polish literature in Lithuania.

On the other hand, Polish literature, which in the Soviet era was a window on the world for the Lithuanian intelligentsia, has now lost its primarily cognitive meaning. Since 1990, we have been dealing with translations which are bound by past ideological directives to a much lesser extent ${ }^{11}$. Joanna Chmielewska is the leader in terms of the number of translated books (twelve works). More important, however, are the names appearing on the covers of Lithuanian literary and cultural journals: Wisława Szymborska, Zbigniew Herbert, Tadeusz Różewicz, Witold Gombrowicz, Stanisław Lem, Olga Tokarczuk, Wiesław Myśliwski, Paweł Huelle, and Tadeusz Konwicki. Currently, the books translated are mainly those which were a commercial success in Poland. They are also the works of winners of various literary competitions.

What, then, does the reception of Tuwim's works look like in Lithuania? When analysing his texts it is impossible to apply the mentioned above historical, cultural and other contexts, within which Polish and Lithuanian literatures coexist.

To the almost rhetorical question of why Lithuanian translators don't translate Tuwim among others, the only Lithuanian Polish studies specialist in Lithuania, Algis Kaleda, answers in an influential journal concerning literature and

\footnotetext{
${ }^{10}$ Ibidem

${ }^{11}$ Ibidem, p. 28.
} 
culture that maybe this poetry is too hard, thus non-modern (or: too hard, because it is non-modern). He claims that in Lithuanian is practically impossible to convey Polish consonant clusters. Currently, translators are focusing on conveying the text semantically, moving away from the phonetic layer ${ }^{12}$. This direction and a similar opinion would be both dubious and quite dangerous from the point of view of probable future translations.

In order to illustrate the elements of today's peculiar reception of Tuwim's works in Lithuania, we need to go back to the interwar period. In May 1927, along with Wacław Borowy, the poet was a guest of "Literary Wednesdays" organized weekly at Konrad's Cell in Vilnius. In the words of a reviewer of the daily "Słowo":

Even the window frames were filled with the associates and - the guests.... $\mathrm{Mr}$ Wacław Borowy took it upon himself to brightly, and not even without harsh criticism, analyse both of Kaden-Bandrowski's books, My Mother's City and In the Shade of the Forgotten Alder. That no broader discussion developed was caused by anxious expectation that Tuwim would speak.... Bur Mr Julian produced only - his manuscript translation of Words About Igor's Regiment and, sitting at the table, began to read. The translation - wonderful.... Almost the whole poem was read out. The poet then added his poem Bulrush ${ }^{13}$.

This was probably Tuwim's only visit to Vilnius, and has become in recent years the object of over-interpretation, but more on this later.

Since there were none of Julian Tuwim's works in the influential literary journals (for instance "Literatūra ir menas" or "Šiaurès Atėnai"), and no Lithuanian researchers were studying his works, their reception could only be reflected by the few books containing the poet's texts and rarely published opinions on his works. In 1952, in Vilnius, a book was published in Polish (twenty four pages) containing works of Julian Tuwim, entitled Selected Poems. In 1956, Tuwim found himself among other Polish authors of humorous works for children in the book About Janek who sews dog's shoes ${ }^{14}$. It also contained works by Jan Brzechwa, Józef Ignacy Kraszewski, and Juliusz Słowacki. However, due to a lack of any reviews of this book, it is impossible to trace its presence on the map of Lithuanian children's literature which underwent various stages of development in all eras primarily based on Lithuanian mythology ${ }^{15}$.

\footnotetext{
${ }^{12}$ Ibidem

${ }^{13}$ J. Hernik-Spalińska, Wileńskie Środy Literackie (1927-1939), IBL, Warsaw 1998, p. 49-50.

${ }^{14}$ Kaip Jonelis šunims batus siuvo. Humoristiniai lenku poetu eilèraščiai vaikams, Valstybinè Grožinès Literatūros Leidykla, Vilinius 1956.

15 The development of Lithuanian children's literature is discussed by K. Urba, Vaiku literatūros patirtis. Straipsnių rinkinys, Šviesa, Kaunas 1995.
} 
In 1962, Ryszard Matuszewski and Zygmunt Stoberski created an anthology of the works of ten Polish poets, entitled 10 lenku poetu ${ }^{16}$ and published in Lithuanian. Among its authors were: Władysław Broniewski, Stanisław Ryszard Dobrowolski, Konstanty Ildefons Gałczyński, Kazimiera Iłłakowiczówna, Jarosław Iwaszkiewicz, Mieczysław Jastrun, Leon Pasternak, Stanisław Piętak, Leopold Staff, and Julian Tuwim. The anthology was created by Polish, not Lithuanian researchers, which is why it cannot serve as basis for conclusions concerning the reception of Polish literature in Lithuania. The short notes about the ten authors take merely three pages, making it impossible to become familiarised with them ${ }^{17}$.

In 2001, The Wroblewski Library of the Lithuanian Academy of Sciences organised an exhibition dedicated to the life and works of Julian Tuwim, but it only comprised of the books found in the library's resources. The latest work, Tuwim's poems, dates to 1994. The event did not stir a lot of interest in the poet's works.

According to the few opinions of one of the most prominent Lithuanian literary critics, Vytautas Kubilius, Tuwim was known in Lithuania for his originals. He mentions the Polish author alongside writers such as Charles Baudelaire, Arthur Rimbaud, Aleksandr Błok, or Siergiej Jesienin, arguing that the writers of a small country should know a few foreign languages so as not to lag behind Western Europe which was the focus of Lithuanian cultural life after the First World War ${ }^{18}$.

The influence of Tuwim's works is noticed (or rather was noticed) in the works of the poet Antanas Miškinis (1905-1983), who in fact translated Tuwim (as well as Broniewski and Słowacki). According to Kubilius, Tuwim shaped the attention to detail in the Lithuanian poet, whose works are a synthesis of modern art and folk tales ${ }^{19}$.

Tuwim became widely known in Lithuania only in 2011, but not because of his works. The Vilnius authorities named one of the streets after him; the street was $10 \mathrm{~km}$ long, running through seven villages inhabited mostly by Poles. This action caused outrage among some of the more nationalistic members of the Lithuanian parliament, who filed a lawsuit to invalidate the decision.

According to Lithuanian law, naming streets and changing their names lies solely in the competence of local government. The Vilnius region is currently governed by Electoral Action of Poles in Lithuania. The law states that the patron

\footnotetext{
${ }^{16} 10$ lenku poetu, comp. R. Matuszewski, Z. Stoberski, Valstybinė Grožinès Literatūros Leidykla, Vilinius 1962.

17 The Lithuanian translation of Historia literatury polskiej by Czesław Miłosz was published only in 1996. A Lithuanian reader can draw information about Polish literature from a recently published book comprising articles by Lithuanian researchers: Zranieni przez czas. Wspótczesna literatura litewska, comp. D. Mitaite, J. Sprindytė, IBL, Warsaw 2011.

${ }^{18}$ V. Kubilius, Šarlio Bodlerio kelias i Lietuva, "Literatūra" 1973, no. XV (3), p. 63.

${ }^{19}$ Idem, Poeto žodis - žaliuojanti rūta, "Literatūra ir menas" 1980, no. 4.
} 
of the street must be a person who has rendered great service to Lithuania. However, before a name is given, The State Commission of the Lithuanian Language has to check if the name is written correctly. It also checks if the person in question is worthy of having a place named after them. The commission found no inadvertence in the proposition to name the street after Juliano Tuvimo.

The petitioners managed to prove to the lower court that Julian Tuwim had rendered great service to Lithuania, and that his works had an influence on the development of Lithuanian literature. One of the arguments being that his mother, Adela Tuwim, née Krukowska, was born in Mariampol.

Why did Julian Tuwim's case need to be settled by a court which is not competent in the area of literature? Can political discourse be an element of the reception of Polish literature in Lithuania? In this case the answer is yes. The discourse engaged Lithuanian society, the political parties, and higher educational establishments whose task was to comment on Tuwim's service to Lithuania.

If we were to agree with the Lithuanian researchers' opinion that Polish literature was always read with probably no reception, then also today there is not much of $\mathrm{it}^{20}$. Although a lack of reception is also a form of reception as it allows for various manipulations and can lead to many misunderstandings, as it was in Tuwim's case.

The lack of conscious reception can also explain some absurd situations which happened in the disagreement about Tuwim's street. In the initial stages of the trial the Vilinius authorities emphasised in their justification that:

the protagonists in Tuwim's poetry are nature, forests, village dwellers, and animals. That is why the name "Juliana Tuwima" would be more fitting for a street, since it runs alongside a forest, and one can take in the beautiful sights of nature and old villages while travelling ${ }^{21}$.

One of the Lithuanian MPs found this explanation to be in violation of the laws regarding naming streets (as it did not contain information about the poet's service to Lithuania). The court of appeal seconded this opinion. Generally speaking, the situation was caused by a certain carelessness of the clerks from the Vilnius region, which was taken advantage of by their opponents who were against the name of the street. The justification or negation of the poet's service to Lithuania was presented only after the extremely nationalistic MP had expressed his discontent.

Julian Tuwim's services to Lithuania were not found by the researchers from The Lithuanian Academy of Sciences. We need to emphasise here that the acad-

\footnotetext{
${ }^{20}$ A. Peluritytė-Tikuišienè, op. cit., p. 351.

${ }^{21}$ See: trial documents concerning Julian Tuwim street litigation in the Vilinius region, A-1462026-12_eteismai.1t\%20(1).pdf [access: 10.10.2013].
} 
emy members are not Polish literature specialists. The Institute of Lithuanian Literature and Folklore confirmed, however, services concerning the poet's indirect relations with Lithuanian culture. The institute found certain similarities with a well-known Lithuanian poet Martynas Vainilaitis (as a children's book author), Eduardas Mieželaitis (as a poet who modernised the Lithuanian lyric genre), and Jonas Aistis (as a poet whose works are uniquely melodic).

What did the body of judges find out about Tuwim from the letters presented by the communities of Polish studies? Mainly that he is a Polish classic poet of Jewish descent, a satirist, a translator of Russian, German, French, and Latin poetry, a scientist, and a great theatre aficionado. Also that his works often touch upon Lithuanian themes, as they describe Lithuanian nature, buildings, people (poems used as a basis for this claim: An event at the rehearsal, Greenery, My little day, Trees of Druskininkai, Polish Flowers). The judges read that Tuwim not only praised Lithuania and the beauty of its nature in his works, but had also actively participated in the cultural life of Vilnius ${ }^{22}$. This was proven by the above quoted visit to Vilnius. Supposedly, it had an impact on Lithuanian literature and the development of Lithuanian national awareness. Of course, such a pursuit for presumed themes in Tuwim's works are a form of abuse, acting solely for the Vilnius authorities or a sheer need to immortalize the poet in the street's name.

In turn, the presence of Tuwim's poems in the workbooks of students of Polish schools in Lithuania did not convince the judges, who stated that it cannot be considered as proof of his service, as the poems are included in the curriculum not for their services to the country, but their artistic, cultural, and didactic value. Moreover, it was argued that they are only found in the workbooks of students of Polish schools.

As a result, the Lithuanian court found that the Vilnius authorities had broken the law and the motion to name one of the streets after Julian Tuwim was invalidated.

To the poet's benefit the whole of Lithuania found out about him.

\section{Bibliography}

Hernik-Spalińska Jagoda, Wileńskie Środy Literackie (1927-1939), IBL, Warsaw 1998.

Kaip Jonelis šunims batus siuvo. Humoristiniai lenku poetu eilèraščiai vaikams, Valstybinè

Grožinès Literatūros Leidykla, Vilinius 1956.

Kalèda Algis, Kaimynų literatūra - kaip sava ir kaip pažistama?, "Krantai” 2013, no. 148.

Kędzierski Igor, Rybałci znad Niewiaży, http://witryna.czasopism.pl/pl/gazeta/1037/1127/1166/

[access: 15.10.2013].

Kubilius Vytautas, Poeto žodis - žaliuojanti rūta, "Literatūra ir menas" 1980, no. 4.

${ }^{22}$ Ibidem. 
Kubilius Vytautas, Šarlio Bodlerio kelias ị Lietuvą, "Literatūra” 1973, no. XV (3).

Kvietkauskas Mindaugas, Pędzac przez tunel czasu. Nowe kierunki w literaturze litewskiej, translated by Z. Mrozikowa, "Literatura na Świecie" 2005, no. 1-2.

Peluritytė-Tikuišienè Audinga, [answers to the questionnaire: How they read us abroad], "Czytanie Literatury" 2012, no. 1.

Trial documents concerning Julian Tuwim's street litigation in Vilinius region, A-146-2026-12 eteismai.lt\%20(1).pdf [access: 10.10.2013].

Urba Kęstutis, Vaiku literatūros patirtis. Straipsnių rinkinys, Šviesa, Kaunas 1995.

Zranieni przez czas. Wspótczesna literatura litewska, comp. D. Mitaitė, J. Sprindytè, IBL, Warsaw 2011.

10 lenku poetu, comp. R. Matuszewski, Z. Stoberski, Valstybinẻ Grožinės Literatūros Leidykla, Vilinius 1962.

Teresa Dalecka

\section{The (Non)Presence of Julian Tuwim in Lithuania}

(Summary)

The reception of Polish literature in Lithuania is a complex phenomenon. For a long time there was a dominant trend of expanding the area of Lithuanian literature by incorporating into it some of the Polish-language authors who maintained contacts with Lithuania. As a result, the horizons of national literature naturally broadened. However, the reception of Julian Tuwim's writing belongs to a different category. It needs to be remembered that in the Soviet period Polish literature offered Lithuanian intellectuals a passage to the outside world. It was in the work of western poets, Tuwim's work included, that Lithuanian authors sought ways of expanding their avant-garde forms and dictions. Tuwim's poetry has been largely read in its original, Polish version; therefore, there are few books collecting his poems. However, the influence of Tuwim's work is recognized by some experts in translations of his work. However, Tuwim was made publicly known in Lithuania thanks an argument over the naming one of the street in Vilnius after his name. The article analysis public reactions to this argument and shows how this non-literaryevent made Tuwim a public figure in the country.

Keywords: Julian Tuwim, Tuwim's reception in Lithuania, Polish literature in Lithuania 